\title{
Code of Ethics for Teachers in Islamic Education Perspective Muhammad Athiyah Al-Abrasyi
}

\author{
Masrizal ${ }^{1}$, Marzuki $^{1}$, Syahrul Awali ${ }^{1}$, Azmi Yudha ${ }^{1}$, Maria Ulfa ${ }^{2}$, Nurul Aida $^{2}$ \\ ${ }^{1}$ Lecturer in Islamic Institute of Islam (IAI) Al-Aziziyah Samalanga Bireuen Aceh \\ 2Student in Islamic Institute of Islam (IAI) Al-Aziziyah Samalanga Bireuen Aceh \\ Email: tgkmasrizal@gmail.com
}

\begin{abstract}
Education can be simply interpreted as an effort to shape human personality in accordance with the values and codes of ethics contained in society and the country. One of the most important components in the learning process is educators and students. Along with the times, there is a shift in the pattern of teacher and student relations; economic values have driven many policies, the appreciation of students towards teachers has decreased, the price of teacher's work is higher, and the teacher's appreciation for him has been lower. Considering the urgency of the teacher's role in the education process, many scholars wrote about the obligations, traits or tasks that the teacher and students had to have. Based on this background, the writer formulates the problem of the teacher's code of ethics in the perspective of Islamic education, Muhammad Athiyah Al-abrasyi. This research is a qualitative descriptive study with the type of library research. The results of this study include personal and professional aspects. The code of ethics of teachers in Islamic education proposed by Muhammad Athiyah al-Abrasyi includes: 1. The code of ethics of teachers relating to themselves; $a$. Be zuhud, $b$. Clean from sin and reprehensible qualities. 2 . The teacher's code of ethics relating to students and fellow teachers; $a$. Be wise and firm, $b$. Forgiving and patient, c. Having dignity and self-esteem, d. Loving students is like loving their own children, e. Knowing students' habits. 3. Code of ethics for teachers related to their duties; a. Sincere at work, b. Mastering the field of study, c. Be able to create active communication between educators and students.
\end{abstract}

Keywords: code of ethics; teachers; Islamic Education

\section{Introduction}

The teacher is the main figure in Islam, the position of the teacher is highly valued if he applies his knowledge by teaching knowledge to others. The high degree and dignity of teachers can be witnessed in real terms today, as in Islamic boarding schools in Indonesia in general and in Islamic boarding schools in Aceh. Santri did not dare to challenge the eyes of his teacher, some bowed when facing the teacher or chaplain. Imagine, they are dazzled by the behavior of teachers who are so noble, his eyes penetrating wide and deep knowledge, and prayers that are believed to be efficacious. This is a small example of appreciation for people who have knowledge. This view will then produce a distinctive and ethical relationship pattern between teacher and student.

The interaction of teacher and student in Islam is not based on profit and loss, because the teacher-student relationship in Islam is essentially a priceless religious relationship. As someone who teaches their knowledge, teachers must maintain attitudes and behavior so that it reflects a noble personality. Along with the times, in Islam there is a shift in the relationship between teacher and student; economic values have driven many policies. Thus, the position of teachers and students in Islam has declined, the appreciation of students towards teachers has decreased, the price of teacher work is higher, and the teacher's appreciation for him is lower.

${ }^{1}$ Ahmad Tafsir, Ilmu Pendidikan dalam Prespektif Islam, (Bandung: Remaja Rosdakarya, 1991), p. 80 
This symptom is a bitter truth that cannot be denied. The teacher is a mirror for students and in general for the community. In each of his actions, he became a role model and example. From here lies the community's appreciation for a teacher. If the teacher cannot display his authority and noble character, then the award disappears little by little. Based on the explanation above, it would be very much needed Islamic educational theories of Islamic thinkers as a renewal of thought and reactualization.

In this writing the writer deliberately chose the thoughts of Muhammad Athiyah alAbrasyi, one of the educational figures who lived during the reign of Abd. al-Nasser who ruled Egypt in 1954-1970 AD Al-Abrasyi was a scholar who had long been involved in the world of education, especially in Egypt which was the center of Islamic science. He made many contributions to the Islamic world. In his wandering knowledge he has made many comparisons made with modern thoughts in the Western world in the $20^{\text {th }}$ century. ${ }^{2}$ So the work he produced is very suitable as a reference and consideration for policy making.

Based on this, Muhammad Athiyah al-Abrasyi's thought regarding the code of ethics that a teacher must possess is a refinement of al-Ghazali's thinking. Therefore it is a strong reason for the writer to raise the teacher's code of ethics in Islamic education which is a study of the thoughts of Muhammad Athiyah al-Abrasyi covering (1). The teacher's code of ethics that relates to itself (2). Teachers' code of ethics relating to students and fellow teachers (3). The teacher's code of ethics for his work.

Based on the above background, the focus of the problem to be investigated is to analysis teacher's of code ethics in islamic education perspective Muhammad Athiyah Al-Abrasyi.

\section{Review of Literature}

\subsection{Teacher's of Code Ethics in Islamic Education}

a. Definition of the Code of Ethics

The use of the term code of ethics is often found in an agency or institutions, especially in agencies or institutions related to services. Because in the code of ethics contains rules regarding the responsibility of oneself, work, clients, relationships, and superiors. ${ }^{3}$ The form of the code of ethics in each agency or institution is very diverse because the code of ethics is a consistency that has been formulated together by the parties involved in an agency or institution.

However, it has an intrinsically similar context that is generally accepted. ${ }^{4}$ A consistency certainly gives birth to consequences. That is, it is a necessity to comply with the code of ethics properly, and certainly will bring sanctions in each violation that arises. ${ }^{5}$ According to Law Number 8 of 1974 concerning Personnel Principles. Article 28 of this Law clearly states that: Civil Servants have a code of ethics as a guideline for attitudes, behavior, and actions within and outside the service. The law expressly explains that the code of ethics is a guideline for the attitude, behavior of a person in carrying out his duties and in everyday relationships.

\footnotetext{
${ }^{2}$ Muhammad Athiyah al-Abrasyi, Dasar-dasar Pokok Pendidikan Islam, (Jakarta: Bulan Bintang), p. ix

${ }^{3}$ Abdul Mudjib dan Jusuf Mudzakkir, Ilmu Pendidikan Islam, (Jakarta: Kencana Prenada Media, 2006), p. 97.

${ }^{4}$ Abdul Mudjib and Jusuf Mudzakkir, Ilmu Pendidikan Islam..., p. 98.

${ }^{5}$ Undang-Undang kepegawaian, (Jakarta, Sinar Grafika, 2005), p. 22
} 
Of all the above meanings, a common thread can be drawn that the code of ethics is a set of norms, moral values that must be respected, internalized, and practiced in carrying out professional duties.

\section{b. Teacher code of ethics}

Teachers are people who get the mandate from those who are unable to educate their children independently. Without the mandate the teacher's title will not be attached to someone. ${ }^{6}$ The mandate is given on the basis of the belief that is embedded in the minds of the community, that the teacher is a person who is able to educate their children and instill the values of life that will lead them to perfection as His servants.

The mandate given by parents to the teacher contains heavy duties and responsibilities, because the teacher's responsibility is not only limited to the walls of the school, but also outside the school. The task of the teacher is not limited to providing knowledge to his students, but he must be able to instill the values of that knowledge in real life.

According to Websty Gibson, quoted by Sardiman, the teacher's code of ethics is said to be a formal statement which is a rule in regulating teacher behavior. ${ }^{7}$ In the duties as a teacher in all actions and he said is an example for his students. If a teacher has committed immoral acts, it means he has violated the teacher's code of ethics that has been set. Because basically intrinsically the code of ethics has the same nature.

In the Teachers and Lecturers Act ninth section on professional organizations and the code of ethics article 43 explains that:

- To maintain and improve teacher's respect and dignity in carrying out professional tasks, the teacher organization forms a code of ethics for teachers.

- The code of ethics as referred to in paragraph 1 contains norms and ethics that bind the teacher's behavior in carrying out professional tasks ${ }^{8}$

The statement above shows that the main purpose of the formation of the teacher's code of ethics is not only as a rule governing the duties of the teacher both in his personal and work.'

So, it is fitting for the teacher to heed and make the code of ethics as a guide in carrying out the tasks they carry. A teacher must have good character and character so that the teacher's task brings good results. These characteristics include: ${ }^{10}$

- Teachers Must Be Fair

In carrying out their duties a teacher must be fair, meaning that they do not differentiate between the differences in their students' treatment. It is absolutely necessary for teachers in the learning process so that there is no gap between one student and another, which will cause students to dislike the teacher and subsequently hate the lessons given by the teacher.

- Teachers Must Believe and Love Their Students

This belief must always be instilled in the heart of a teacher, that the students they teach also have a great willingness to develop their potential. Then, it is the teacher's job to help students develop that potential.

\footnotetext{
${ }^{6}$ Hery Noer Aly, Ilmu Pendidikan Islam, Jakarta: Logos Wacana Ilmu, 1999, p. 93.

${ }^{7}$ Sardiman, Interaksi dan Motivasi Belajar Mengajar: Pedoman Bagi Guru dan Calon Guru, Cet. V, Jakarta: Raja Grafindo Persada, 1994, p. 150.

${ }^{8}$ Undang-Undang Guru dan Dosen (Jakarta: Sinar Grafika, 2005), p. 21.

9Soetjipto dan Raflis Kosasi, Profesi Keguruan, Jakarta: Rineka Cipta, 1999), pp. 30-31.

${ }^{10}$ Ngalim Purwanto, Ilmu Pendidikan Teoritis dan Praktis, (Bandung: Remadja Karya, 1988), pp. 176-182.
} 
- Teachers must be patient and willing to sacrifice

In dealing with every aspect of this life, patience must be the main foundation that someone must pay attention to. Especially for a teacher who gets the mandate from parents to educate their children.

- Teachers should be cheerful people.

A teacher should have a high sense of humor and be able to place it in every learning. This is very necessary so that students do not get bored quickly and get bored receiving lessons.

- Be nice to other teachers

Respecting and doing good to others is an obligation for everyone. Likewise, fellow teachers have the same obligation to maintain the honor and dignity of their peers. The behavior of students is strongly influenced by the atmosphere of the teacher's environment.

- Be nice to the community

The school environment is a small part of the community environment that is used as a provision for children to live in the wider community. Thus, the teacher's task is not only limited to the walls of the school, but also in society in general.

- Teachers Must Really Master the lesson

In mastering the material the teacher must always add and expand his knowledge.

\section{c. Code of Ethics for Teachers}

In Islamic education, the use of the term code of ethics is rarely used. Educational leaders are more likely to use the traits, tasks and obligations that must be possessed by teachers. Attention of scholars to education is so great. So that not a few of the scholars who have written about matters relating to the teacher. Scholars who have great attention to this issue include alGhazali (d. $505 \mathrm{H})$.

Regarding the qualities that must be possessed by the teacher both in his duties and outside his duties have been used as a source of reference for the scholars afterwards, including Muhammad Athiyah al-Abrasyi who tried to perfect al-Ghazali's thought about the code of ethics of an Islamic education teacher. ${ }^{11}$

Furthermore, Al-Ghazali explained that when someone has assumed the mandate to become a teacher, then he is carrying out a very large job and faces no small danger. Then the manners that must be considered by a teacher include: ${ }^{12}$

- Teachers should view students as their own children; love and treat them like their own children.

- A teacher should not expect anything from his students, be it wages, salaries, praise, thanks or other replies.

- Teachers should take advantage of every opportunity to give advice and remind students that the purpose of studying is to draw closer to God rather than seeking position and wealth in the world.

- Teachers should not be rude to their students. If there are students who make mistakes as much as possible to be reminded in a subtle way or by insinuating it with parables, not by denouncing, reprimanding, or cursing students because it will make students disobedient and deliberately violate.

\footnotetext{
${ }^{11}$ Ahmad Tafsir, Ilmu Pendidikan dalam Prespektif Islam, Bandung: Remaja Rosdakarya, 1991, p. 82.

${ }^{12}$ Ibya' al-Ghozali, Terjemahan ..., pp. 212-223.
} 
- For students who are weak in understanding, teachers should provide information that makes it easy for students to understand the lesson. So he has a high enthusiasm in learning.

\section{Research Method}

The method used in this paper is to refer to the method developed by Jujun Suriasumantri, namely critical analytical descriptive. According to Suriasumantri, this method is the development of a descriptive method or what is known as analytical descriptive, which describes human ideas without a critical analysis. Critical analytical methods aim to examine primary ideas about a scope of problems enriched by relevant secondary ideas. ${ }^{13}$ The focus of critical analytical writing is to describe, discuss and criticize primary ideas which are then "confronted" with other primary ideas in an effort to conduct studies in the form of comparisons, relationships and model development.

Source of data needed in this study, primary data are works that have been written by figures who are the focus of research. ${ }^{14}$ Besides that, secondary data is also needed, that is data taken from library materials that are relevant to the thoughts of Muhammad Athiyah Al-Abrasyi about Islamic education in general and specifically on the ethical values of educators.

In accordance with the type and nature of the data obtained from the study, the analysis used is the Content Analysis technique. With this technique, the qualitative textual data obtained will be sorted (sorted), described, discussed and criticized. Then categorized with similar data, and analyzed its contents critically in order to get a concrete and adequate formulation.

\section{Discussion}

\subsection{A Short Biography of Muhammmad Athiyah Al-Abrasyi}

Prof. Dr. Muhammmad Athiyah al-Abrasyi was an educational figure who lived during the reign of Abd. al-Nasser who ruled Egypt in 1954-1970 AD.

The educational thought of Muhammmad Athiyah al-Abrasyi was inspired by many Islamic education figures before their time. Like Imam Al-Ghazali, Ibn Khaldun and other figures of his time. Al-Abrasyi is very confident that the concept of education offered by previous Islamic thinkers was very influential and succeeded in giving birth to highly qualified scholars and scholars, such as Ibn Sina, Ibn Rushd, al-Farabi, al-Ghazali, Ibn Khaldun, Thabrani, Ibn Kathir and others.

Muhammad Al-Abrasyi argues that the principles of modern education which began to be developed in the mid-21st century which until now developed countries have not been able to apply it fully, have been noted and implemented in Islamic education.

The thoughts of Muhammmad Athiyah al-Abrasyi in the fields of education and noneducation include the following works:

\footnotetext{
${ }^{13}$ Jujun S. Sumantri, Scientific Research, Philosophy and Religion: Looking for a Common Paradigm in the New Tradition of Islamic Research: Interdisciplinary Review (Bandung: Nuance in collaboration with Pusjarlit Press, 1998), pp. 41-61.

${ }^{14}$ Lexy J. Moleong, Pendidikan Kualitatif, (Bandung: Rosdakarya, 2002), p. 164.
} 
1. Spirit of al-Islam

2. 1 Adlmat al-Islam, Juz I-II

3. 'Adlmat al-Rasul Muhammad SAW.

4. al-Tarbiyah Islamiyah Wa Falsafatauha

5. Ruh al-Tarbiyah Wa at-Ta'lim

6. al-Ijtihad al-Hadith fi al-Tarbiyah

7. al-Thuruq al-Khoshoh fi al-Tarbiyah Litadris al-Lughoh al-Arabiah Wa al-Din

8. al-Thufulah Shani 'at al-Mustaqbal aw Kaifa Nurabbi Athfalana

9. al-Ilm Shi'ar al-Tsaurat al-Tsaqofiyah

10. 'Ilm al-Nafas al-Tarbawi

11. Usul al-Tarbiyah wa Qawa 'Idal-Taaris

12. 'Ilm al-Nafsi al-Tarbawi

13. Lughoh al-Arabiah Wa Kaifa Nanhadlu Biha

14. al-Tarbiyah Wa al-Hayat

15. 'Ilm al-Nafsi Lil Jami'

16. Misykat al-Ta'lim al-'Ula Bi Mishr

17. Min Wahyi al-Tsaurah

18. al-Fashlfi Lughat al-Swyansyah wa Adabiha

19. Qishashfi al-Buthulah wa al-Wathanfyah

20. Maktabat al-Thifl al-Dmiyah.

21. Qishash Diniyah U al-Athfal.

\subsection{Teacher Code of Ethics Muhammmad Athiyah al-Abrasyi's perspective}

All aspects of life have been arranged in it. Including the problem of science, Islam highly glorifies the degree of people who are knowledgeable and practice it. As the phrase says:

"The teacher is the spiritual father or spiritual father of a student, who will provide soul food with knowledge, moral education, and justify it, then respecting the teacher means respect for our children, respecting the teacher means respect for our children." ${ }^{15}$

According to Muhaimin that competencies that must be possessed by a teacher include; religious personal competence (religious personality), social religious (caring for social problems), and professional religious (the ability to carry out their duties in accordance with Islamic guidance).

Muslim philosophers have a lot of ideas about the code of ethics of teachers, which are then much refined by Islamic thinkers afterwards, which are adjusted to the period in which they live. As an Islamic thinker in the 20th century, Muhammad Athiyah al-Abrasyi also put forward his concept of a teacher's code of ethics in Islamic education that relates to oneself, with the teacher, with the student, also with the tasks he entails.

a.. The teacher's code of conduct relating to oneself

- . Zuhud

Zuhud means raghaba 'an syai'in wa tarakahu, meaning not interested in something and leaving it. ${ }^{16}$ However, the meaning of zuhud here is not leaving the world completely. As

\footnotetext{
${ }^{15}$ Muhammad Athiyah al-Abrasyi, Al-Tarbiyah Al-Islamiyah Wa Falsafatauba (Al-Baaby al-Halaby), p.139.

${ }^{16} \mathrm{Ahmad}$ Warsun Munawwir, kamus al-Munawwir..., p. 262.
} 
revealed by al-Abrasyi in the aim of Islamic education that one of the goals of Islamic education is to balance the world and the hereafter. ${ }^{17}$

Al-Abrasyi explained that a teacher occupies a high and holy place, and he must know the obligations according to his position as a teacher, so he must really be a zuhud, who teaches with the intention of seeking the pleasure of Allah, not because of receiving salary or compensation. services. And do not want to teach it other than seeking God's pleasure and spreading knowledge." 18

- Clean from sin and reprehensible qualities

The teacher is a mirror for his students, their every action will be imitated by them. Al-Abrasyi stated:

"A teacher must clean his body and limbs, away from sin and guilt, clean the soul, avoid big sins, joyful nature '(looking for names), envy, enmity, strife, and others from despicable qualities." ${ }^{19}$

b. The teacher's code of ethics relating to students and fellow teachers

- Be wise and firm

A wise and firm attitude must be attached to the teacher, both in his words and actions. He also must be wise in addressing everything that is in the form of policy making. In this case al-Abrasyi appealed:

Meek without showing weakness and hard without showing violence." 20

- Forgiving and patient

Patience means being steadfast. ${ }^{21}$ Associated with the task of teachers who not only transfer of knowledge, but also guide and educate students to develop their potential. AlAbrasyi said:

"A teacher must be forgiving of his students, he is able to hold back, hold back anger, be generous, be patient, and not be angry because of trivial things." 22

Often a teacher is negligent with his work, so he can not hold back and hold back his anger over the mistakes made by his students. Teacher's anger is sometimes acted out in the form of punishment or harsh treatment of students which will result in the authority and self-esteem of the teacher.

- Having dignity and dignity

Authority is defined as an attitude or appearance that gives rise to a sense of reticence and respect, so that students feel protected and protected. In this relationship, the gurus must maintain authority and honor, avoiding things that are despicable, which can lower their dignity. Like, shouting, angry, or doing something that is not appropriate for a teacher. Al-Abrasyi explained:

\footnotetext{
${ }^{17}$ Muhammad Athiyah al-Abrasyi, Dasar-dasar...,p.133.

${ }^{18}$ Muhammad Athiyah al-Abrasyi, Al-Tarbiyah Al-Islamiyah ..., p.140.

${ }^{19}$ Muhammad Athiyah al-Abrasyi, Al-Tarbiyah..., p. 140

${ }^{20}$ Muhammad Athiyah al-Abrasyi, Al-Tarbiyah..., p. 141

${ }^{21}$ Muhammad Athiyah al-Abrasyi, Al-Tarbiyah..., p. 141.

${ }^{22}$ Muhammad Athiyah al-Abrasyi, Al-Tarbiyah..., p. 141.
} 
Authority and dignity, guarding honor, avoiding despicable and lowly things, refraining from anything bad, not making noise and shouting so that he is respected and respected." ${ }^{23}$

Authority and self-esteem are very dependent on the quality of the teacher, who is calm, peaceful, and always maintains the words of his actions. This trait is an impact of the patience that the teacher has. High authority and self-esteem will have an impact on respect and appreciation from outside himself, both from his soul, colleagues, and parents of students. The kindness that is safeguarded by a person will certainly bring good fruit as well.

- Loving students is like loving their own children

The teacher is the second parent for his students. So, in the learning process the teacher's right to educate and guide children is greater than the rights of parents because parents have given the mandate to the teacher to replace the assignment that should be his responsibility. In treating students, al-Abrasyi is in line with Al-Ghazali who requires a teacher to love his students as he loves his own biological child. al-Abrasyi said:

Even al-Abrasyi added, that a teacher should love his students more than his own children. $^{24}$

This is where the teacher's opportunity to give love and love that is not obtained at home. None of the parents neglect their children. The need for knowledge and guidance. The teacher will always think about the difficulties faced by students and will think of ways to get them out of those difficulties.

- Knowing students' habits

Al-Abrasyi explained: (habits), tastes, and thoughts of his students, so that he is not wrong in educating them."

This is what voiced by education experts today. The teacher's knowledge of the behaviors, habits, tastes, and thoughts of the student or it can be said that the psychology of child development will greatly assist the teacher in carrying out their duties.

As al-Abrasyi said: "Paying attention to these things in teaching will help them choose the appropriate field of study that is in line with their level of understanding."

In this case al-Abrasyi also agreed with al-Ghazali to always pay attention to the phase of student development. To always give lessons according to their level of understanding and not force them to understand something they haven't been able to digest.

\subsection{Code of Ethics for Teachers Related to Their Duties}

a. Sincere at work

Modern materialist lifestyles have been widely adopted by educators. If this attitude continues to be followed by the teacher, then sincerity is lost in the teacher who is called to develop the nature and nature of the students. The sincere attitude of a heart that is willing to

\footnotetext{
${ }^{23}$ Muhammad Athiyah al-Abrasyi, Al-Tarbiyah..., p. 141.

${ }^{24}$ Muhammad Athiyah al-Abrasyi, Dasar-dasar..., p. 138.
} 
sacrifice for students, which is characterized by honesty, openness, and patience is one's motivation to do work. As the expression al-Abrasyi:

"Truly the sincerity of a teacher in his work is the best way towards success in the tasks and success of his students." 25

Al-Abrasyi's explanation above is very clear that a teacher also holds an important factor in his success and the success of his students. Sincerity in the teacher in fulfilling his vocation, is one of the important factors that is often neglected by the teacher. In this case al-Abrasyi agrees with Hadari an-Nahlawi who also requires a teacher to have this quality. Because this is the nature that will create a pleasant learning situation. ${ }^{26}$

Furthermore, al-Abrasyi explained that a teacher is sincere not only when he does not have a primary goal that is material in teaching. Included as sincere is when the words in accordance with his actions, carry out what was said, and not ashamed to say do not know when he did not know. ${ }^{27}$

Al-Abrasyi also added that a teacher who is sincere in carrying out his duties will not be ashamed to say he does not know, if there are things he does not know and is not ashamed to learn from his students. Al-Kanani also agrees with al-Abrasyi. So, when there are questions and he cannot answer, he will be willing to submit answers to students who can answer.

In line with this, al-Ghazali explains that a pious person who is truly pious is one who still feels he must always increase his knowledge and established himself as a student to look for true nature. Besides that he was sincere towards his students and kept his time. ${ }^{28}$

This sincere attitude will lead the teacher to success. In addition, by having this attitude, a teacher really wholeheartedly applies his knowledge, not only fulfilling his duties as a teacher, but wants to guide children to learn science, instill it, and encourage them to practice the knowledge they already have.

\section{b. Mastering the field of study}

This competency is an obligation for a teacher. Even along with the times, teachers must always deepen their knowledge and broaden their horizons so that their knowledge is not obsolete, out of date, and not in accordance with the times. Al-Abrasyi explained:

"A teacher must be able to master the field of study that he provides, as well as deepen his knowledge about it, so that the field of study is not superficial, does not quench thirst, and does not satisfy hunger." 29

As al-Kanânî argues, a teacher should familiarize himself with his spare time with useful things and should be diligent in researching, composing, and composing by paying attention to skills and expertise..$^{30}$ Always review and develop the knowledge he has. ${ }^{31}$

\footnotetext{
${ }^{25}$ Muhammad Athiyah al-Abrasyi, Al-Tarbiyah ..., p. 140

${ }^{26}$ Khoiron Rosyadi, Pendidikan profetik, (Yogyakarta: Pustaka Pelajar, 2004), p. 186

${ }^{27}$ Muhammad Athiyah al-Abrasyi, Dasar-dasar..., p. 138.

${ }^{28}$ Abuddin Nata, Filsafat pendidikan Islam, (Logos Wacana Ilmu, 1997) p. 74

${ }^{29}$ Muhammad Athiyah al-Abrasyi, Al-Tarbiyah..., p. 142.

${ }^{30}$ Heri Noer Aly, Ilmu Pendidikan..., p. 101.

${ }^{31}$ Pendapat Abdurrahman An-Nahlawi yang dikutip oleh Muhaimin dalam Muhaimin, dkk., Paradigma Pendidikan Islam..., p. 95
} 
c. Able to create active communication between educators and students

Communication patterns in interactions can be applied in the learning process. Communication patterns in education can be done with, namely communication as action (unidirectional interaction), communication as interaction (multi-directional interaction). ${ }^{32}$

In its compilation, Muhammad Athiyah al-Abrasyi's thoughts were much in line with the thoughts of the previous scholars, especially al-Ghazali. Apparently, he wanted to perfect alGhazali's thinking in this field. But he rather summarizes the traits that appear to overlap. However, al-Abrasyi's thoughts about the code of ethics of teachers in Islamic education are only in broad outline, not in detail.

Al-Abrasyi's thoughts are still very relevant to education today, starting from the aim of his education which is more focused on moral education to form humans who have perfect morals. Although the purpose of education which is initiated is more focused on the formation and refinement of morals, but it does not neglect other education, such as education in life skills, vocational, carpentry and the like are also considered. This is nothing but to balance between the world and the hereafter which is also part of the stated educational goals.

The concept of the teacher's code of ethics that he brought up was also very relevant to education today. He not only paid attention to the personal aspects of religion, but he also paid attention to the teacher's competence which must always be improved. That is, he also paid attention to increasing teacher professionalism.

\section{Conclusions}

The code of ethics of teachers in Islamic education in the perspective of Muhammad Athiyah al-Abrasyi includes:

\subsection{The teacher's code of ethics relating to oneself;}

a. Are zuhud

b. Clean from sin and reprehensible qualities.

\subsection{The teacher's code of ethics relating to students and fellow teachers}
a. Be wise and firm
b. Forgiving and patient
c. Having dignity and dignity
d. Loving students is like loving their own children
e. Knowing students' habits

\subsection{Code of ethics for teachers related to their duties}

a. Sincere at work

b. Mastering the field of study

c. Able to create active communication between educators and students

\footnotetext{
${ }^{32}$ Saiful Bahri, Syarkawi Syarkawi, Mursal Mursal, Fizazuawil Fizazuawil, Maimun Maimun, Trust Giving Transactions on Mu'amalah Al-Wadi'ah, Budapest International Research and Critics Institute-Journal (BIRCIJournal) Volume 2 No. 1, 2019, p. 54. (http://bircu-journal.com/index.php/birci/article/view/51-57).
} 


\section{References}

Abdul Mudjib and Jusuf Mudzakkir. (2006). Ilmu Pendidikan Islam, Jakarta: Kencana Prenada Media.

Abuddin Nata. (1997). Filsafat pendidikan Islam, $1^{\text {st }}$ Print, Logos Wacana Ilmu.

Ahmad Tafsir. (1991). Ilmu Pendidikan dalam Prespektif Islam, Bandung: Remaja Rosdakarya.

Hery Noer Aly. (1999). Ilmu Pendidikan Islam, Jakarta: Logos Wacana Ilmu, 1999.

Ibya' al-Ghozali, (1979). Translated by Ismail Yakub, Cet. Ke VI, Semarang: Faizan.

Jujun S. Sumantri. (1998). Penelitian Ilmiah, Kefilsafatan dan Keagamaan: Mencari Paradigma Bersama dalam Tradisi Baru Penelitian Agama Islam: Tinjauan antar Disiplin Ilmu, Bandung: Nuansa bekerjasama dengan Pusjarlit Press.

Khoiron Rosyadi. (2004). Pendidikan profetik, Cet. I, Yogyakarta: Pustaka Pelajar.

Lexy J. Moleong. (2002). Pendidikan Kualitatif, Bandung: Rosdakarya.

M. Amin Syukur. (1997). Zubud di Abad Modern, Yogyakarta: Pustaka Pelajar.

M. Djumransyah. (2006). Filsafat Pendidikan, Malang: Bayu Media.

Muhaimin et al. (2004). Paradigma Pendidikan Islam: Upaya mengefektifkean Pendidikan Agama Islam (PAI) di Sekolah, $4^{\text {th }}$ Print. Bandung: Remaja Rosda Karya.

Muhammad Athiyah al-Abrasyi, Al-Tarbiyah Al-Islamiyah Wa Falsafatauha, Al-Baaby al-Halaby.

Muhammad Athiyah al-Abrasyi, Dasar-dasar Pokok Pendidikan Islam, Jakarta: Bulan Bintang.

Nana Sujana. (1989). Cara Belajar Siswa Aktif dalam Proses Belajar Mengajar, Bandung: Sinar Baru.

Ngalim Purwanto. (1998). Ilmu Pendidikan Teoritis dan Praktis, Bandung: Remadja Karya.

Sardiman. (1994). Interaksi dan Motivasi Belajar Mengajar: Pedoman Bagi Guru dan Calon Guru, $5^{\text {th }}$ Print, Jakarta: Raja Grafindo Persada.

Soetjipto and Raflis Kosasi. (1999). Profesi Keguruan, Jakarta: Rineka Cipta, 1999.

Undang-Undang Guru dan Dosen. (2005). Jakarta: Sinar Grafika.

Undang-Undang kepegawaian. (2005). Jakarta, Sinar Grafika. 